\title{
Spatial Heterogeneity in Environmental Regulation Enforcement and the Firm Location Decision among U.S. Counties*
}

\section{O. Ashton Morgan and Simon Condliffe $e^{+}$}

\begin{abstract}
We estimate a negative binomial model with fixed effects to examine the impact of spatial differences in environmental regulation on manufacturing capital flows. Using a newly available data set, we find that stricter air quality standards with respect to ozone deter births of polluting plants, suggesting that heterogeneity in regulatory standards may create a spatial browning process. We also find that spatial differences in environmental regulation do not play a role in the location decision of plants that are not pollution-intensive. Finally, we also examine the effects on capital flows with respect to three other criteria air pollutants regulated under the amendments to the Clean Air Act. We find that births of particulates-intensive manufacturers are deterred by stricter regulation with respect to particulates emissions but the location decisions of plants that emit high levels of carbon monoxide and sulfur dioxide are not significantly affected by increased regulation of the respective criteria pollutant.
\end{abstract}

Keywords: Environmental regulation, firm location, air pollution

JEL Classifications: $R 38, Q 28, Q 53$

\section{INTRODUCTION}

Prior to the creation of the Environmental Protection Agency in 1970, environmental regulation control was in the hands of state and local authorities. Opponents of local control over environmental regulation argued that this created a "race to the bottom" phenomenon where local legislators had incentives to set sub-optimum environmental regulatory standards in an attempt to attract polluting industries to the area. The decentralized status of air quality regulation and rising ambient concentration levels led to Congress creating administrative bodies such as the Environmental Protection Agency (EPA) and the Council on Environmental Quality to enforce new regulatory statutes. The EPA created national ambient air quality standards (NAAQS) under the newly formed National Environmental Policy Act and amendments to the Clean Air Act (CAA), designed to clean up source emissions for air pollution in the United States.

Since then, an academic debate has emerged regarding whether a relationship exists between federal air quality regulations and the capital flows of pollution-intensive manufacturing plants. The intuition behind the debate is that if spatial heterogeneity in environmental regulatory standards creates significant differences in private compliance costs, then these costs should be factored into a firm's location decision. As such, pollution-intensive manufacturers may be deterred from opening new plants in areas with stricter regulations. Much of the earlier research

\footnotetext{
* The authors thank the anonymous reviewers and the Editors for their comments and insights throughout the review process.

+ Morgan is Assistant Professor of Economics at Appalachian State University; Condliffe is Assistant Professor of Economics and Finance at West Chester University.

Contact author: O. Ashton Morgan, Department of Economics, Appalachian State University, Boone, NC 28608. E-mail: morganoa@appstate.edu.
}

C Southern Regional Science Association 2011.

ISSN 1553-0892

SRSA, 1601 University Avenue, PO Box 6025, Morgantown, West Virginia 26506-6025, USA. 
suggests that, at most, any relationship between environmental regulation stringency and the location decision of pollution-intensive births is negligible (see Bartik, 1988; McConnel and Schwab, 1990; Duffy-Deno, 1992; Jaffe et al., 1995; and Levinson, 1996). However, more recent work specifically considers the impact of the CAA on the capital flows of pollution-intensive manufacturers and typically finds that increased regulatory standards deters pollution intensive births (see List et al., 1999; Becker and Henderson, 2000; List, 2001; List, McHone, and Millimet, 2004a; Becker, 2005).

Under the CAA, each year every county in the U.S. is designated as being either inattainment or out-of-attainment with regard to federal air quality standards for each of six criteria pollutants. The six criteria air pollutants are tropospheric ozone $\left(\mathrm{O}_{3}\right)$, particulates $(\mathrm{PT})$, carbon monoxide $(\mathrm{CO})$, sulfur dioxide $\left(\mathrm{SO}_{2}\right)$, nitrogen dioxide $\left(\mathrm{NO}_{2}\right)$, and lead $(\mathrm{Pb})$. Under the CAA, new plants are subject to significantly different start-up costs dependent on the attainment status of the county. Firms locating new plants in a county designated as being out-of-attainment are subject to the Lowest Achievable Emission Rate (LAER) on equipment. Regulatory compliance is enforced without any cost consideration to the firm and can entail significant start-up costs. These costs can comprise additional capital expenditures on air pollution abatement (APA) equipment and/or operating costs on new staff or more expensive materials. In contrast, firms locating new plants within in-attainment counties are subject to a less restrictive regulatory standard known as Prevention of Significant Deterioration (PSD). In this case, only firms that have the potential to emit more than 100 tons of a criteria pollutant (Class A polluters) in a year must install the Best Available Control Technology (BACT), where the cost burden on the firm is taken into account in the decision making process. Further, low-polluting firms are not subject to regulatory standards in areas designated as in-attainment. Overall, local regulators have discretion in the methods they choose to bring non-attainment areas into attainment as they target "dirty" industries; however, it is the firms themselves that are directly regulated, not the industries.

For an example of the recent work examining the firm behavioral impacts of the CAA and NAAQS non-attainment status, Becker and Henderson (2000) consider manufacturing plant location from 1963 to 1992 and find that ozone air quality regulations significantly reduce the number of births of high emitters in non-attainment areas relative to attainment areas. List and McHone (2000) use county-level annual ozone attainment status as their measure of air quality regulation and consider county-level plant births in New York State from 1980 to 1990. They find that a county's ozone status change from attainment to non-attainment does significantly reduce births of "dirty" plants. Further, Kahn (1997) finds 14 percent lower growth in manufacturing births of plants considered high emitters of PT between 1982 and 1988. Finally, Becker (2005) takes a different approach to other firm behavior studies by examining the impact of stricter regulations under the CAA on air pollution abatement (APA) capital expenditures and operating costs. As the Census Bureau's Pollution Abatement Costs and Expenditures (PACE) survey data are frequently used as proxies for regulatory stringency in firm location studies, the overall purpose of the study was to test whether underlying PACE survey responses are correlated with environmental stringency measures. Becker (2005) considers four of the CAA's criteria air pollutants in a probit and tobit model framework. Results from the logit model indicate that generally, heavy emitters of the criteria pollutants had a greater likelihood of nonzero APA expenditures. Further, results from the tobit model specification show that these heavy emitters are faced with APA expenditures in the region of hundreds of thousands of dollars. 
Overall, recent research examining firm behavior in relation to county-level NAAQS non-attainment status provides evidence that greater environmental stringency deters births of pollution-intensive manufacturers. These results have important policy implications as it suggests that federal air quality regulations have unintended consequences stemming from the CAA by altering regional capital formation. If environmental regulations are an important consideration in pollution-intensive manufacturers' site location decisions, this may create a spatial browning process as polluting manufacturers are less likely to site new plants in areas with increased start-up costs.

The purpose of this research is to use a newly available county-specific data set on establishment births to examine the impact of air quality regulation on the location decisions of pollution-intensive manufacturing plants across the U.S. Following research by Becker and Henderson (2000), List and McHone (2000), and List et al. (2003), we are primarily interested in examining the firm location impacts of increased regulatory standards with respect to ozone under the CAA. We focus on ozone for three main reasons. First, as discussed by List, McHone, and Millimet (2004a), of the six criteria pollutants, ozone has attracted the most regulatory attention due to the limited success in reducing its concentration levels in the U.S. Second, List and McHone (2000) reason that as attainment status for the criteria pollutants can include partial standards between attainment and non-attainment, county-level ozone status has been typically polar in nature with counties either specifically in- or out-of-attainment. Finally, of all the criteria pollutants, more counties have been designated as out-of-attainment with respect to ozone emissions. However, to expand the analysis, following Becker (2005), we also examine manufacturing firms' location behavior with regard to other criteria pollutants. In total, we consider four of the six criteria pollutants; ozone, PT, $\mathrm{CO}$, and $\mathrm{SO}_{2}$. County nonattainment status effects with regard to $\mathrm{NO}_{2}$ emissions are not tested as there are very few counties in a nonattainment status during the studied time period. Also, we do not test county nonattainment status effects vis-à-vis airborne lead as county lead attainment status was not listed in the Code of Federal Regulations during this time period. As Becker (2005) points out, it is also highly unlikely that any counties were in non-attainment status with regard to lead emissions, as in May 2004 , only a portion of three counties were categorized as such.

Our estimates from a fixed effects negative binomial model indicate that the expected number of pollution-intensive plant openings decreases by approximately nine percent each year that a county is out-of-attainment with respect to ozone standards. As the set-up costs imposed by the LAER standards significantly detract births of polluting manufacturers away from nonattainment counties, we hypothesize that clean births will not be impacted by spatial differences in regulation. In terms of ozone attainment status, results from a non pollution-intensive model support this hypothesis. Results from models examining the impacts of non-attainment status with regard to the other criteria pollutants are mixed. We find that county-level non-attainment status with regard to PT emissions also deters births of heavy PT-emitting manufacturers but the location decisions of high-emitting $\mathrm{CO}$ and $\mathrm{SO}_{2}$ plants are not significantly affected by a county's non-attainment status of the respective pollutant.

\section{DATA}

We develop a county-level panel data set on establishment births and deaths from 1996 to 2000, across all counties in the contiguous United States. The data are collected under the Statistics of U.S. Businesses program at the U.S. Census Bureau. Establishment data are 
compared against equivalents from the prior year to discern whether the business is new, i.e. a birth, or continuing. The data are verified to ensure that businesses that are merely renamed are not counted as new. The births data are arranged as inter-year flows, e.g. establishment births between 1996 and 1997. Each establishment is coded by geography and industry (Standard Industrial Classification (SIC)). This provides a level of detail beyond most comparable studies, plus the micro level panel data set avoids many of the data constraints and estimation biases apparent in previous studies. These studies typically find an insignificant or, at best, marginal relationship between environmental regulation stringency and firm location decisions. Nonetheless, more recent studies have highlighted the failure of cross-sectional models to properly control for the simultaneous nature of firm location and pollution problems (c.f. List and McHone, 2000; and Brunnermeier and Levinson, 2004). Essentially, cross-sectional studies consider differences in environmental regulations across counties at one point in time. Hence, they do not fully disentangle the positive correlations between higher pollution levels and more stringent environmental regulation. As a result, coefficient estimates are likely biased. In contrast, the use of panel data allows the analysis to consider differences in new firm births in a county over time as a function of variation in the county's environmental regulation over the same period. As panel models can also control for county-specific fixed effects, we are able to overcome the limitations of previous cross-sectional studies.

Other advantages of this data set over earlier studies accrue from the micro level data on establishment births. For example, due to data limitations, some earlier studies used aggregate measures of establishment data and changes in the stock of plants as the dependent variable. As environmental regulatory measures based on attainment status are more stringent toward new plants locating in the area, use of aggregate plant stock data may miss the regulatory effects on the flow of plant births. Our data set exploits plant births as a measure of changes in manufacturing establishments, which should make our measure more sensitive to changes in environmental regulation at the county level. Also, many previous studies employ data from the Census of Manufacturing database that is only available every five years (Levinson, 1996; Becker and Henderson, 2000; and List, 2001). Therefore, to generate the independent variable, plant births are aggregated across five-year intervals. This temporal aggregation of births creates potential problems since plants can wind up being omitted from the data base entirely as they open and shut down within a given five-year window.

Finally, the data also allow us to analyze the relationship between environmental regulation stringency and firm location by pollution-intensity of manufacturing sectors. As the county-level attainment status is determined by air-quality measures, we follow Greenstone (2002) and List (2004a) by focusing on a set of pollution-intensive industrial sectors based on their ozone emission levels. Greenstone (2002) classifies sectors as ozone-pollution-intensive if they emit at least 6 percent of the total sector's emissions of the primary chemical precursors to ozone. ${ }^{1}$ As establishment data are disaggregated by SIC code, we consider plants as being pollution-intensive if they are in the following SIC codes: 2611-2631 (Pulp and Paper Mills), 2711-2789 (Printing and Binding), 2812-2819 (Industrial Inorganic Chemicals), 2911 (Petroleum Refining), 30 (Rubber and Misc. Plastics), 32 (Stone, Clay, and

\footnotetext{
${ }^{1}$ Namely, volatile organic compounds and nitrogen oxide.

(c) Southern Regional Science Association 2011.
} 
TABLE 1. States with the Highest County-level Non-attainment Status

\begin{tabular}{llll}
\hline \hline Ozone & Carbon Monoxide & Sulfur Dioxide & Particulates \\
\hline Pennsylvania (44) & California (22) & Minnesota (8) & California (15) \\
California (27) & New Jersey (14) & Ohio (7) & Colorado (11) \\
Ohio (25) & Colorado (9) & Indiana (5) & Montana (7) \\
New York (22) & Minnesota (8) & Arizona (4) & Arizona (7) \\
New Jersey (20) & New York (7) & Pennsylvania (3) & Washington (6) \\
Total (325) & Total (112) & Total (45) & Total (78) \\
\hline \hline
\end{tabular}

Glass), 3312-3313 (Steel and Electrometallurgical Products), 3321-3325 (Iron and Steel Foundries), 34 (Fabricated Metal Products), and 371 (Motor Vehicles and Equipment). All other industries are coded as nonpollution-intensive. ${ }^{2}$

We also follow Becker (2005) by examining three other criteria air pollutants: particulates (PT), carbon monoxide $(\mathrm{CO})$, and sulfur dioxide $\left(\mathrm{SO}_{2}\right)$. While Becker (2005) examines PACE survey data to investigate the effects of the CAA on plants' capital expenditures and operating costs, we investigate increased regulatory stringency on high emitters of these criteria air pollutants in a more traditional firm location analysis. Table A1 in the Appendix provides a breakdown of industries considered high emitters of PT, $\mathrm{CO}$, and $\mathrm{SO}_{2}$.

With regard to PT, $\mathrm{CO}$, and $\mathrm{SO}_{2}$, we follow Becker (2005) by categorizing high emitters based on data from the EPA's Aerometric Information Retrieval System (AIRS) database. AIRS data are also classified by SIC and detail U.S. establishments that emit a threshold amount of each of the six criteria air pollutants. For $\mathrm{CO}$, the threshold is set at 1,000 tons per year. For all others, it is 100 tons per year. As threshold levels for each criteria pollutant are set by the EPA, Becker (2005) calculates the number of establishments that emit over the threshold level. An industry (and therefore any plant that operates within that industry) is labeled as a high emitter of each pollutant if it has a minimum number of plants above the threshold level. In each case, the minimum number of establishments was set so that no more than 50 percent of plants were designated as a high emitter of any pollutant.

In terms of ozone, there are 325 counties that are designated as out-of-attainment over the four-year period (Table 1). The majority of these counties are located in Pennsylvania (44), California (27), and Ohio (25). Of the 325 counties, over this time frame 68 counties changed status from out-of-attainment to attainment between 1996 and 2000. For PT, 78 counties were designated as out-of-attainment over the four-year period with the majority of counties located in California (11), Colorado (11), and Montana (7). Of these counties, only five changed attainment status over this period. ${ }^{3}$ There were 112 out-of-attainment counties with respect to $\mathrm{CO}$ with California (22), New Jersey (14), and Colorado (9) contributing most counties. Of these, 47 counties changed status during the period. Finally, 45 counties were designated as out-of-

\footnotetext{
${ }^{2}$ Two-digit SIC codes are disaggregated to their three-digit components. For example SIC 32 is divided into its three-digit components. Four-digit SIC codes are aggregated to three-digit levels. For example, SIC 2812-19 is treated as 281, which encompass the codes 2812 through 2819.

${ }^{3}$ As capital flows are identified only by counties that change attainment status during the four-year period, the low number of observations for attainment status change with regard to PT may result in a lack of statistical significance of the attainment variable in the PT model as the rare event (change in county-level PT status) is overwhelmed by the non-event (no change in status).
}

(C) Southern Regional Science Association 2011. 
attainment with regard to $\mathrm{S}_{2}$ with the majority of counties located in Minnesota (8), Ohio (7), and Indiana (5). Of these, 16 counties changed status between 1996 and 2000.

Table 2 displays the counties with the greatest number of establishment births by type of firm (all births, ozone-polluting, carbon monoxide, sulfur dioxide). Certain counties reappear in each ranking, for example, Los Angeles, New York, and Orange Counties.

Table 3 reports the number of establishment births by pollutant. Particulate-polluting establishment births were the most numerous during the four-year period (55,567 births). Sulfur dioxide-polluting establishment births ranked second in the data (38,115 births). Ozone-intensive plant births numbered 27,830, and carbon monoxide births numbered 24,694.

\section{THE MODEL}

Early work by Carlton (1983) and Bartik (1985) employed a conditional logit approach to firm level data. This approach works well when the choice set of possible locations is relatively small, e.g. counties in a particular state. But it quickly becomes difficult to estimate as the choice set expands, e.g. when hundreds of counties are contained in the choice set. A solution is proposed by Guimarães et al. (2003) wherein the equivalence between the likelihood function of the conditional logit and a Poisson regression is exploited for an easy to estimate model irrespective of the number of locations in the choice set.

We follow Becker and Henderson $(1997,2000)$ and List and McHone (2000) in deriving the reduced-form model, using a flow concept of new births as the dependent variable, allowing the effects of increased stringency in environmental regulation to be captured in a partial equilibrium framework.

\section{TABLE 2. Highest Ranking Counties for Establishment Births by Polluting Industry 1996-2000}

\begin{tabular}{rlllll}
\hline \hline Rank & All Births & Ozone & Carbon Monoxide & Sulfur Dioxide & Particulates \\
\hline 1 & Los Angeles, CA & Los Angeles, CA & Los Angeles, CA & Los Angeles, CA & Los Angeles, CA \\
2 & Cook, IL & New York, NY & Orange, CA & Orange, CA & Orange, CA \\
3 & New York, NY & Cook, IL & Cook, IL & Cook, IL & Harris, TX \\
4 & Harris, TX & Orange, CA & Harris, TX & Harris, TX & Cook, IL \\
5 & Maricopa, AZ & Maricopa, AZ & Maricopa, AZ & San Diego, CA & San Diego, CA \\
6 & Orange, CA & Harris, TX & San Diego, CA & Maricopa, AZ & Maricopa, AZ \\
7 & San Diego, CA & San Diego, CA & Dallas, TX & Dallas, TX & Dallas, TX \\
8 & Dallas, TX & Dallas, TX & Broward, FL & New York, NY & King, WA \\
9 & King, WA & King, WA & New York, NY & King, WA & Broward, FL \\
10 & Broward, FL & Broward, FL & King, WA & Broward, FL & New York, NY \\
\hline \hline
\end{tabular}

TABLE 3. Establishment Births by Industry 1996-2000

\begin{tabular}{lc}
\hline \multicolumn{1}{c}{ Polluting Industry } & Number of Establishment Births \\
\hline Ozone & 27,830 \\
Carbon Monoxide & 24,694 \\
Sulfur Dioxide & 38,115 \\
Particulates & 55,567 \\
\hline \hline
\end{tabular}

(C) Southern Regional Science Association 2011. 
The supply of entrepreneurs in any given time period is given by:

$$
Y_{i t}\left(\prod\left(X_{i t}, e_{i t}\right)\right)
$$

where $Y_{i t}$ is the flow of new plants (gross births), $\mathrm{X}_{i t}$ are spatial attributes that affect the local profit function, $\Pi$, and $e_{i t}$ is a random error component. The supply curve is upward-sloping as an increase in per plant profit induces new births. A demand curve represents the change in plant profits due to an increase in births. So we have:

$$
\Pi^{d}\left(Y_{i t}\right)
$$

The demand curve can be positively or negatively sloped as profit can be positively affected by births through localization or urbanization economies, or it can be negatively affected by births as new plants may have a negative impact on local output price. The intersection of the demand and supply functions gives a reduced-form equation:

$$
Y_{i t}=f\left(X_{i t}\right)+e_{i t}
$$

where $Y_{i t}$ is births in county $i$ in time $t ; X_{i t}$ is a vector of county attributes, including attainment status and time dummies, presumed to influence the spatial location function; and $e_{i t}$ is a contemporaneous independently and identically distributed error term.

As the dependent variable, new plant births, is a nonnegative integer with a high frequency of small numbers, $Y_{i t}$ is modeled as a Poisson distributed random variable. The probability that a plant will open in county $i$ in time $t$ is given by the basic Poisson probability function:

$$
\operatorname{prob}\left(Y_{i t}\right)=\frac{e^{-\lambda_{i t}} \lambda_{i t}^{y_{i t}}}{Y_{i t} !}, \quad y=0,1,2, \ldots .
$$

where $\lambda_{i t}$ is the expected value of new plant births and is assumed to be a function of the variables specified in the model. Usually, $\lambda_{i t}$ takes a log-linear form to ensure nonnegative birth counts and may be written as:

$$
\lambda_{i t}=e^{x_{i t} \beta+\alpha_{i}},
$$

Where $\beta$ is a vector of unknown coefficients to be estimated and $\alpha_{i}$ are unobservable countyspecific factors that may affect the location decision. As $\alpha_{i}$ are important, we account for the county-specific unobservables by estimating a fixed effects panel data model. In estimation, county-specific unobservables that do not vary over time are accounted for in the model as each unit of observation is conditioned on total births for that county over the sampling period. As such, the likelihood function becomes:

$$
\operatorname{prob}\left(Y_{i 1}, Y_{i 2}, \ldots . Y_{i T} \mid \sum_{t} Y_{i t}\right)=\frac{\left(\sum_{t} Y_{i t}\right) !}{\prod_{t}\left(Y_{i t} !\right)} \prod_{t}\left[\frac{e^{x_{i t} \beta}}{\sum_{t} e^{x_{i t} \beta}}\right]^{Y_{i t}},
$$

The fixed effects, $\alpha_{i}$, are therefore conditioned out of the likelihood function and are unrecoverable. One potentially undesirable characteristic of the Poisson model is the restriction that the conditional mean and variance of the dependent variable, $\lambda_{i t}$, are equal. This can be a

(C) Southern Regional Science Association 2011. 
limiting assumption as standard errors from a Poisson model are sensitive to under- or overdispersion in the data. As such, the negative binomial model is a less restrictive, natural alternative to the Poisson model since it allows for differences in the mean and variance.

We gathered data on new plant births for 3,042 counties over the four-year period from 1996 to 2000. We dropped 126 counties from the model due to missing county-level employment and income data. The remaining 2,916 counties generated 11,664 observations to be used in the panel model. The explanatory variable of interest is attainment status under the federal standard for air criteria pollution, which follows research by Henderson (1996), Kahn (1997), Becker and Henderson (2000), and List and McHone (2000). More specifically, as these studies find significant effects on industry behavior vis-à-vis county non-attainment status with respect to their chosen air criteria pollutant, we follow Becker (2005) by examining the firm behavioral impacts of non-attainment status in relation to criteria air pollutants for four CAAs. As other county-specific firm location research has used county-specific descriptors, we also include county-level population, manufacturing employment, and income as explanatory variables since they may influence the firm location decision (see Becker and Henderson, 2000; List and McHone, 2000; List, McHone, and Millimet, 2004b). ${ }^{4}$ Descriptive statistics, definitions, and sources are shown in the Table A2 in the Appendix.

\section{RESULTS}

Table 4 presents results from the fixed-effects negative binomial models. For the four criteria air pollutants considered here, we test the impact of county-level attainment status on dirty manufacturing births and nonpolluters. In total we run eight models. We are particularly interested in ozone non-attainment status and other location-specific effects on high-emitter births (Model 1) due to the relative lack of progress in reducing its concentration levels. Also, of all the criteria pollutants, more counties have been designated as out-of-attainment with respect to ozone emissions and there are more within-county status changes over the four-year period of our data.

As the underlying assumption within the analysis is that nonpolluting or clean manufacturers should not be affected by attainment status, we also examine attainment-status effects on clean births. Before discussing the results, some preliminary observations are required. First, when estimating, we assume the attainment status variable is strictly exogenous; nonetheless, we recognize the potential for endogeneity of this variable. That is, new pollutionintensive firm births in year $t$ in county $i$ can push the county out of attainment with respect to air quality levels in year $t+1$. We follow List and McHone (2000) and empirically check for endogeneity by comparing the model results with those using lagged attainment status values. The coefficients do not change much, indicating that endogeneity is not a serious issue with our general model. Second, for all models we performed the Hausman test to identify whether the coefficients estimated by the efficient random-effects estimator are the same as the ones

\footnotetext{
${ }^{4}$ In an earlier version of the analysis, we also gathered data on county-level highway expenditures and property tax revenues to estimate and include an effective property tax variable. Unfortunately, consistent data are not available for all counties across all years. For example, the quinquennial survey of government finances takes place in years ending in two and seven (e.g. 1992, 1997, and 2002). In these survey years all counties are surveyed. During the intervening years only a subset of counties are sampled: those counties with populations greater than 100,000. In order to estimate a balanced panel, we did not include countylevel highway expenditures or effective property taxes in the model.
}

(C) Southern Regional Science Association 2011. 


\section{TABLE 4. Fixed-Effects Negative Binomial Model of Births of Clean and Dirty Manufacturers}

\begin{tabular}{|c|c|c|c|c|c|c|c|c|}
\hline & \multicolumn{2}{|c|}{ Ozone } & \multicolumn{2}{|c|}{$\mathrm{PT}$} & \multicolumn{2}{|c|}{$\mathrm{CO}$} & \multicolumn{2}{|c|}{$\mathrm{SO}_{2}$} \\
\hline & Model 1 & Model 2 & Model 3 & Model 4 & Model 5 & Model 6 & Model 7 & Model 8 \\
\hline & Dirty & Clean & Dirty & Clean & Dirty & Clean & Dirty & Clean \\
\hline & Births & Births & Births & Births & Births & Births & Births & Births \\
\hline \multirow[t]{2}{*}{ Constant } & $26.414 * *$ & 0.799 & 12.120 & $5.634 * *$ & 5.728 & 1.891 & 17.306 & 1.725 \\
\hline & 4.188 & 1.509 & 164.243 & 1.742 & 4.786 & 1.568 & 143.648 & 1.600 \\
\hline \multirow[t]{2}{*}{ Attain } & $-0.087 *$ & 0.006 & $-0.489 * *$ & $-0.266 * *$ & -0.066 & 0.032 & -0.014 & $0.041 * *$ \\
\hline & 0.053 & 0.031 & 0.208 & 0.136 & 0.050 & 0.031 & 0.026 & 0.022 \\
\hline \multirow[t]{2}{*}{$\ln ($ pop) } & $2.109 * *$ & 0.267 & -0.279 & $0.816^{* *}$ & -0.704 & 0.258 & -0.014 & 0.230 \\
\hline & 0.462 & 0.176 & 0.407 & 0.200 & 0.547 & 0.181 & 0.498 & 0.186 \\
\hline \multirow[t]{2}{*}{$\ln (\mathrm{empl})$} & 0.233 & $0.176^{* *}$ & -0.020 & 0.086 & -0.160 & $0.226 * *$ & 0.103 & $0.234 * *$ \\
\hline & 0.151 & 0.049 & 0.092 & 0.059 & 0.142 & 0.052 & 0.119 & 0.053 \\
\hline \multirow[t]{2}{*}{$\ln ($ inc $)$} & $-2.179 * *$ & 0.033 & $0.481 *$ & $-0.509 * *$ & 0.381 & -0.063 & 0.047 & -0.051 \\
\hline & 0.376 & 0.156 & 0.261 & 0.177 & 0.404 & 0.161 & 0.315 & 0.165 \\
\hline \multirow[t]{2}{*}{1997} & $0.076^{* *}$ & $-0.117 * *$ & $-0.099 * *$ & $-0.135 * *$ & $-0.073 * *$ & $-0.125^{* *}$ & $-0.062 * *$ & $-0.142 * *$ \\
\hline & 0.028 & 0.014 & 0.017 & 0.020 & 0.026 & 0.016 & 0.021 & 0.017 \\
\hline \multirow[t]{2}{*}{1998} & $0.763 * *$ & $0.464 * *$ & $-0.218 * *$ & $0.959 * *$ & $-0.169 * *$ & $0.602 * *$ & $-0.148 * *$ & $0.678 * *$ \\
\hline & 0.044 & 0.019 & 0.030 & 0.024 & 0.046 & 0.020 & 0.037 & 0.021 \\
\hline \multirow[t]{2}{*}{1999} & $0.788 * *$ & $1.016^{* *}$ & $-0.292 * *$ & $1.689 * *$ & $-0.209 * *$ & $1.216 * *$ & $-0.185^{*} *$ & $1.327 * *$ \\
\hline & 0.058 & 0.023 & 0.040 & 0.028 & 0.060 & 0.024 & 0.048 & 0.025 \\
\hline Log Lik. & -7336 & -17912 & 14687 & -17918 & -7975 & -17919 & -16314 & -16315 \\
\hline
\end{tabular}

Notes: Standard errors in parentheses *Denotes significance at the 10 percent level $* *$ Denotes significance at the 5 percent level

estimated by the consistent fixed-effects estimator. For all models we reject the null hypothesis, which suggests that a fixed-effects model is appropriate.

Model 1 of Table 5 presents the affect of ozone attainment on ozone-intensive plant births. The results provide some interesting insight into the impact of air quality regulation on firm location behavior. For pollution-intensive manufacturers, the results provide evidence that births are deterred by increased regulatory costs. Recall, plants locating within counties that are designated as being out-of-attainment with regard to the federal standards for ozone are subject to the Lowest Achievable Emission Rate (LAER) on equipment, and this is enforced without consideration of cost to the firm. This is in contrast to new plants locating within in-attainment counties that are subject to less restrictive start-up costs. The coefficient on the attainment status variable is negative and significant at the 10 percent confidence level. This estimate suggests that the expected number of pollution-intensive plant openings decreases by approximately 9 percent each year that a county is designated as out-of-attainment with respect to ozone standards. Compared to other research, our result is slightly smaller than Henderson's (1996) finding in which a county's out-of-attainment status deters expected births of new plastic manufacturing plants by 11 to 12 percent. Based on our results, each county reports 2.2 new ozone pollutionintensive plant births each year on average, representing a decrease of 0.19 expected births per year for counties designated as out-of-attainment with respect to ozone standards. This is somewhat smaller than List and McHone's (2000) finding that non-attainment status decreased the expected flow of dirty manufacturing births by 0.88 between 1985 and 1990 in New York State. Still, it is in line with the results of List, McHone, and Millimet (2004a), which translate 
the attainment-status parameter in a fixed-effects Poisson model into an expected loss of 0.140.20 domestically owned new plants between 1980 and 1990. The policy implication of our finding is that, as an unintended consequence of the CAA 1977, differences in the federal standards for ozone may cause a spatial browning process as more stringent air quality regulations affect capital flows of pollution-intensive plants.

In terms of the location-specific variables in Model 1, on the demand side, an area's population positively influences the capital flows to polluting plants. This perhaps suggests that firms are attracted to higher populated counties to take advantage of labor market economies by sharing a common labor pool. The number of manufacturing employees is also positive, albeit insignificant. Higher personal income deters ozone pollution-intensive births. While empirical evidence regarding income effects on plant births is inconclusive, our result lends support to environmental justice concerns that polluting manufacturers locate plants in disproportionately poorer areas.

In Model 2, we examine the relationship between environmental regulatory stringency and capital flows of nonpolluting or clean manufacturers. We hypothesize that while the LAER on equipment imposes significant private compliance costs on dirty plants, environmental stringency should not influence the location decision of clean plants. The attainment status is insignificant, suggesting that, in contrast to polluting plants, a county's ozone attainment status has no impact on the location decision of clean plants. This implies that the regulatory costs imposed on new plants locating in out-of-attainment counties are not a significant component of the location decision for clean plants.

We also examine non-attainment status and other location-specific effects vis-à-vis PT, $\mathrm{CO}$, and $\mathrm{SO}_{2}$ (Becker 2005). Models 3 and 4 consider the impact of attainment status with respect to PT on dirty and clean births respectively. Again the attainment status coefficient is negative and significant; counties designated as out-of-attainment with regard to PT deter births of manufacturing plants considered to be high emitters of PT. While Becker (2005) did not consider location effects, this result lends support to his finding that PT non-attainment is more likely to affect capital and operating cost expenditures for high-emitting firms. Interestingly, based on Model 4 results, the additional expenditures incurred also seem to deter clean birthsalthough the coefficient is much smaller. Income is again negative and significant, which suggests higher-income areas are less likely to attract PT-producing firms than are low-income areas.

While Models 5 and 7 indicate that county-level attainment status in regard to $\mathrm{CO}$ and $\mathrm{SO}_{2}$ negatively impacts the location behavior of high emitters of the respective criteria pollutants, the coefficients are insignificant. This may be due to a relatively low national priority toward regulating high emitters of $\mathrm{CO}$ and $\mathrm{SO}_{2}$, or perhaps due to the lack of within-county attainment changes. This result is consistent with Becker (2005), who also finds that nonattainment status with regard to $\mathrm{CO}$ has no impact on capital expenditures of high emitters and is actually less likely to affect operating costs.

\section{CONCLUSION}

We investigate whether federal air quality standards impact capital flows. Under the 1977 CAA, new plants locating in counties designated as out-of-attainment of the federal standards for six criteria air pollutants face stricter regulations. As the regulation is enforced without any cost

(C) Southern Regional Science Association 2011. 
consideration to the firm, this can impose significant start-up costs. As such, the intuition is that heterogeneous regulatory stringency could play a major role in a firm's location decision. While earlier research typically finds an insignificant or, at best, a marginal relationship between regulatory standards and capital flows, more recent research provides statistical support for this hypothesis. We use a newly available panel data set of county-level manufacturing plant births between 1996 and 2000. The focus of the paper is on ozone attainment effects, since the relative lack of progress in reducing the concentration levels of ozone has received much attention from regulators of late. Further, our data reveal that more counties have been designated as out-ofattainment with respect to ozone emissions and that there are many within-county status changes over the four-year period. We find that more-stringent air-quality regulations with respect to ozone deter births of pollution-intensive plants. This supports the idea that asymmetrical spatial environmental standards create a spatial browning process. The underlying assumption is that if dirty plants are deterred from locating in out-of-attainment counties due to the high start-up costs imposed, spatial differences should not influence capital flows to clean plants. Results from a second model on nonpollution-intensive manufacturers support this hypothesis, finding that attainment status with respect to ozone has no statistical effect on the birth rate of clean plant.

Finally, we examine the impact of increased regulatory standards with respect to PT, CO, and $\mathrm{SO}_{2}$ on dirty and clean births. Our results show that increased regulatory standards related to PT deter both high- and low-PT-emitter births in a statistically significant fashion. Increased regulatory standards related to high-emitter $\mathrm{CO}$ or $\mathrm{SO}_{2}$ births are negatively related to establishment births but are not statistically significant.

\section{REFERENCES}

Bartik, Timothy J. (1985) "Business Location Decisions in the United States: Estimates of the Effects of Unionization, Taxes, and Other Characteristics of States," Journal of Business \& Economic Statistics, 3, 14-22.

(1988) "The Effects of Environmental Regulation on Business Location in the United States," Growth and Change, 19, 22-44.

Becker, Randy A. (2005) "Air Pollution Abatement Costs Under the Clean Air Act: Evidence from the PACE Survey," Journal of Environmental Economics and Management, 50, 144-169.

Becker, Randy A. and J. Vernon Henderson. (2000) "Effects of Air Quality Regulation On Polluting Industries," Journal of Political Economy, 108, 379-421.

Brunnermeier, Smita B. and Arik Levinson. (2004) "Examining the Evidence on Environmental Regulations and Industry Location," Journal of Environment and Development, 13, 6-41.

Carlton, Dennis W. (1983) "The Location and Employment Choices of New Firms: An Econometric Model with Discrete and Continuous Endogenous Variables," Review of Economics and Statistics, 65, 440-449.

Duffo-Deno, Kevin T. (1992) "Pollution Abatement Expenditures and Regional Manufacturing Activity," Journal of Regional Science, 32, 419-436.

Greenstone, Michael. (2002) "The Impacts of Environmental Regulations on Industrial Activity: Evidence from the 1970 and 1977 Clean Air Act Amendments and the Census of Manufacturers," Journal of Political Economy, 110, 1175-1219.

(C) Southern Regional Science Association 2011. 
Guimarães, Paulo, Octávio Figueirdo, and Douglas Woodward. (2003) “A Tractable Approach to the Firm Location Decision Problem," Review of Economics and Statistics, 85, 201-204.

Henderson, J. Vernon. (1996) "Effects of Air Quality Regulation," American Economic Review, 86, 789-813.

Jaffe, Adam B., Steven R. Peterson, Paul R. Portney, and Robert N. Stavins. (1995) "Environmental Regulation and the Competitiveness of U.S. Manufacturing: What Does the Evidence Tell Us?," Journal of Economic Literature, 33, 132-163.

Kahn, Matthew E. (1997) "Particulate Pollution Trends in the United States, Regional Science and Urban Economics, 27, 87-107.

Levinson, Arik. (1996) "Environmental Regulations and Manufacturer's Location Choices: Evidence from the Census of Manufacturers," Journal of Public Economics 61, 5-29.

List, John. (2001) "U.S. County-level Determinants of Inbound FDI: Evidence from a Two-Step Modified Count Data Model," International Journal of Industrial Organization, 19, 953973.

List, John and Warren McHone. (2000) "Measuring the Effects of Air Quality Regulations on 'Dirty' Firm Births: Evidence from the Neo- and Mature-Regulatory Periods," Papers in Regional Science, 79, 177-190.

List, John, Warren McHone, Junsoo Lee, and Mark Soskin. (1999) "Effects of Air Quality Regulation on Manufacturing Births: Evidence from a Panel of Counties in New York State," Department of Agricultural and Resource Economics, University of Maryland Working Paper: College Park, Maryland.

List, John, Warren McHone, and Daniel Millimet. (2004a) "Effects of Environmental Regulation on Foreign and Domestic Plant Births: Is There Home Field Advantage?," Journal of Urban Economics, 56, 303-326.

. (2004b) "The Unintended Disincentive in the Clean Air Act," Advances in Economic Analysis \& Policy, 4, 1204-1204.

List, John, Daniel Millimet, Per Fredriksson, and Warren McHone. (2003) "Effects of Environmental Regulations on Manufacturing Plant Births: Evidence from a Propensity Score Matching Estimator," Review of Economics and Statistics, 85, 944-952.

McConnell, Virginia D. and Robert M. Schwab. (1990) "The Impact of Environmental Regulation on Industry Location Decisions: The Motor Vehicle Industry," Land Economics 66, 67-81.

(C) Southern Regional Science Association 2011. 


\section{APPENDIX}

\section{Table A1. SIC Codes for High Emitting Industries by Criteria Air Pollutants}

\section{Particulates (PT)}

2016,2032,2034,2037,2041,2043,2046,2047,2048,2061,2062,2063,2074,2075,2076,2079,2082, $2083,2491,2085,2087,2095,2099,2211,2261,2262,2272,2281,2411,2421,2426,2431,2435,2436$, $2439,2449,2492,2499,2511,2521,2522,2611,2621,2631,2641,2647,2649,2661,2752,2816,2819$, $2821,2822,2823,2824,2833,2834,2841,2851,2861,2865,2869,2873,2874,2879,2892,2895,2899$, $2911,2951,2952,2999,3011,3069,3079,3211,3221,3229,3231,3241,3251,3255,3271,3272,3273$, $3274,3275,3281,3291,3295,3296,3297,3299,3312,3313,3315,3316,3317,3321,3322,3325,3331$, $3332,3333,3334,3339,3341,3353,3354,3361,3362,3399,3423,3431,3444,3462,3494,3519,3531$, $3532,3585,3624,3634,3711,3714,3715,3731,3732,3743,3761,3764,3825,3996,3999$.

\section{Carbon Monoxide (CO)}

2034,2046,2061,2062,2063,2272,2421,2436,2492,2499,2611,2621,2631,2649,2752,2813,2816, $2819,2821,2824,2861,2865,2869,2873,2895,2899,2911,2951,2999,3241,3255,3274,3296,3312$, $3321,3322,3331,3333,3334,3339,3341,3351,3551,3585,3589,3624,3711,3714,3861$.

\section{Sulfur Dioxide $\left(\mathrm{SO}_{2}\right)$}

2011,2013,2016,2022,2023,2032,2033,2037,2041,2046,2047,2048,2061,2062,2063,2066,2075, $2077,2079,2082,2083,2085,2091,2099,2111,2141,2211,2231,2253,2261,2262,2269,2272,2295$, $2297,2421,2491,2492,2499,2511,2522,2611,2621,2631,2641,2647,2649,2754,2812,2816,2819$, $2821,2822,2824,2833,2834,2841,2844,2861,2865,2869,2873,2874,2875,2879,2892,2895,2899$, 2911,2951,2952,2999,3011,3041,3069,3079,3111,3211,3221,3229,3241,3251,3255,3271,3272, $3273,3274,3275,3291,3295,3296,3297,3299,3312,3313,3316,3321,3331,3333,3334,3339,3341$, $3465,3483,3519,3523,3531,3568,3585,3624,3711,3714,3721,3724,3743,3861,3996,3999$.

(C) Southern Regional Science Association 2011. 
TABLE A2. Descriptive Statistics

\begin{tabular}{|c|c|c|c|}
\hline Variable & $\begin{array}{l}\text { Mean } \\
\text { (Std. Dev.) }\end{array}$ & Description & Source \\
\hline $\begin{array}{l}\text { Pollution intensive } \\
\text { births (ozone) }\end{array}$ & $\begin{array}{r}2.24 \\
(9.13)\end{array}$ & $\begin{array}{l}\text { Count of new ozone pollution- } \\
\text { intensive plants from } 1996 \text { to } 2000 \text {. }\end{array}$ & $\begin{array}{l}\text { Census Statistics of U.S. } \\
\text { Businesses }\end{array}$ \\
\hline $\begin{array}{l}\text { Nonpollution-intensive } \\
\text { plants (ozone) }\end{array}$ & $\begin{array}{r}14.52 \\
(67.11)\end{array}$ & $\begin{array}{l}\text { Count of new ozone clean plant births } \\
\text { from } 1996 \text { to } 2000 \text {. }\end{array}$ & $\begin{array}{l}\text { Census Statistics of U.S. } \\
\text { Businesses }\end{array}$ \\
\hline $\begin{array}{l}\text { Pollution intensive } \\
\text { births (PT) }\end{array}$ & $\begin{array}{r}4.48 \\
(13.87)\end{array}$ & $\begin{array}{l}\text { Count of new PT pollution-intensive } \\
\text { plants from } 1996 \text { to } 2000 .\end{array}$ & $\begin{array}{l}\text { Census Statistics of U.S. } \\
\text { Businesses }\end{array}$ \\
\hline $\begin{array}{l}\text { Nonpollution-intensive } \\
\text { plants (PT) }\end{array}$ & $\begin{array}{r}12.28 \\
(64.11)\end{array}$ & $\begin{array}{l}\text { Count of new clean PT plant births } \\
\text { from } 1996 \text { to } 2000 \text {. }\end{array}$ & $\begin{array}{l}\text { Census Statistics of U.S. } \\
\text { Businesses }\end{array}$ \\
\hline $\begin{array}{l}\text { Pollution intensive } \\
\text { births (CO) }\end{array}$ & $\begin{array}{r}1.99 \\
(6.38)\end{array}$ & $\begin{array}{l}\text { Count of new CO pollution-intensive } \\
\text { plants from } 1996 \text { to } 2000 .\end{array}$ & $\begin{array}{l}\text { Census Statistics of U.S. } \\
\text { Businesses }\end{array}$ \\
\hline $\begin{array}{l}\text { Nonpollution-intensive } \\
\text { plants (CO) }\end{array}$ & $\begin{array}{r}14.77 \\
(70.21)\end{array}$ & $\begin{array}{l}\text { Count of new clean CO plant births } \\
\text { from } 1996 \text { to } 2000 .\end{array}$ & $\begin{array}{l}\text { Census Statistics of U.S. } \\
\text { Businesses }\end{array}$ \\
\hline $\begin{array}{l}\text { Pollution intensive } \\
\text { births }\left(\mathrm{SO}_{2}\right)\end{array}$ & $\begin{array}{r}3.07 \\
(11.04)\end{array}$ & $\begin{array}{l}\text { Count of new } \mathrm{SO}_{2} \text { pollution-intensive } \\
\text { plants from } 1996 \text { to } 2000 .\end{array}$ & $\begin{array}{l}\text { Census Statistics of U.S. } \\
\text { Businesses }\end{array}$ \\
\hline $\begin{array}{l}\text { Nonpollution-intensive } \\
\text { plants }\left(\mathrm{SO}_{2}\right)\end{array}$ & $\begin{array}{r}13.69 \\
(66.20)\end{array}$ & $\begin{array}{l}\text { Count of new clean } \mathrm{SO}_{2} \text { plant births } \\
\text { from } 1996 \text { to } 2000 .\end{array}$ & $\begin{array}{l}\text { Census Statistics of U.S. } \\
\text { Businesses }\end{array}$ \\
\hline $\begin{array}{l}\text { Attainment Status } \\
\text { (ozone) }\end{array}$ & $\begin{array}{r}0.09 \\
(0.29)\end{array}$ & $\begin{array}{l}\text { Dichotomous variable }=1 \text { if county is } \\
\text { out-of-attainment of federal standards } \\
\text { for ozone, } 0 \text { otherwise. }\end{array}$ & $\begin{array}{l}\text { Federal Register Title } 40 \\
\text { CFR Part } 81.305 .\end{array}$ \\
\hline Attainment Status (PT) & $\begin{array}{r}0.02 \\
(0.16)\end{array}$ & $\begin{array}{l}\text { Dichotomous variable }=1 \text { if county is } \\
\text { out-of-attainment of federal standards } \\
\text { for PT, } 0 \text { otherwise. }\end{array}$ & $\begin{array}{l}\text { Federal Register Title } 40 \\
\text { CFR Part } 81.305 .\end{array}$ \\
\hline $\begin{array}{l}\text { Attainment Status } \\
\text { (CO) }\end{array}$ & $\begin{array}{r}0.03 \\
(0.17)\end{array}$ & $\begin{array}{l}\text { Dichotomous variable }=1 \text { if county is } \\
\text { out-of-attainment of federal standards } \\
\text { for } \mathrm{CO}, 0 \text { otherwise. }\end{array}$ & $\begin{array}{l}\text { Federal Register Title } 40 \\
\text { CFR Part } 81.305 .\end{array}$ \\
\hline $\begin{array}{l}\text { Attainment Status } \\
\left(\mathrm{SO}_{2}\right)\end{array}$ & $\begin{array}{r}0.02 \\
(0.13)\end{array}$ & $\begin{array}{l}\text { Dichotomous variable }=1 \text { if county is } \\
\text { out-of-attainment of federal standards } \\
\text { for } \mathrm{SO}_{2}, 0 \text { otherwise. }\end{array}$ & $\begin{array}{l}\text { Federal Register Title } 40 \\
\text { CFR Part } 81.305 .\end{array}$ \\
\hline Population & $\begin{array}{r}87.69 \\
(287.98)\end{array}$ & County population $(1,000 \mathrm{~s})$ & County Business Patterns \\
\hline Employment & $\begin{array}{r}6.52 \\
(21.78)\end{array}$ & $\begin{array}{l}\text { Total manufacturing employment } \\
(1000 \mathrm{~s})\end{array}$ & County Business Patterns \\
\hline Income & $\begin{array}{r}2,287,639 \\
(8,416,989)\end{array}$ & County personal income $(\$ 1,000)$ & $\begin{array}{l}\text { Bureau of Economic } \\
\text { Analysis }\end{array}$ \\
\hline
\end{tabular}

(C) Southern Regional Science Association 2011. 